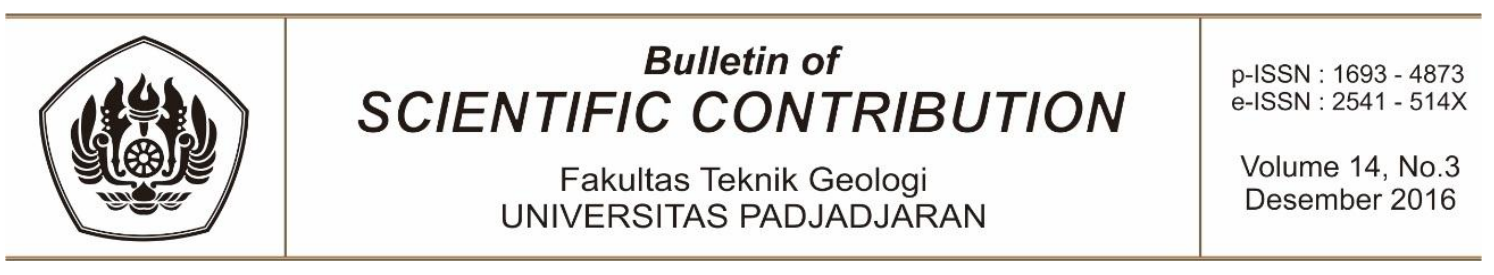

\title{
Characteristic of volcanic deposits in the southern part of Gunung Karang, Pandeglang, West Java
}

\author{
Abdurrokhim and Ismawan \\ abdurrokhim@unpad.ac.id \\ Fakultas Teknik Geologi - Universitas Padjadjaran
}

\begin{abstract}
In the southern part slope of Gunung Karang in Pandeglang, there are many well-outcrops of volcanic materials that developed during Quaternary. The deposits represent various lithofacies both vertically and laterally.

In general the lithologic characteristics that are found in the study area can be grouped into three units, (1). Tertiary sedimentary rock, which is consists of tuffaceous mudstones interbedded with fine-grained tuffaceous sandstone and siltstone, (2) primary volcanic product consist of andesite lava flow, volcanic breccia/agglomerate, and pyroclastic rocks (ash tuff, lapilli tuff, bomb/block, and lapilli tuff breccia, and (3) secondary volcanic products, which is consisting of laharic breccia and coarse-grained thick-bedded sandstone.

In general the deposits become younger to the top of topography (Gunung Karang), but locally the deposits are most likely overlapping each other's.
\end{abstract}

Keywords : Volcanic Deposits, Gunung Karang

\section{Background}

The geology of Quaternary volcanic product in the western part of Java Island have been studied by several researcher (e.g. Rusmana, Suwitodirdjo, \& Suharsono, 1991; Santosa, 1991), but however detail characteristic and stratigraphic relationship of those volcanic products are not described in detail. The distribution and contact lithofacies of those product are also not been well reported.

This paper intends to discuss the lithologic lithofacies characteristic of volcanic materials on basis of volcanic nomenclature and genetic processes (e.g. (McPhie, Doyle, \& Alllen, 1993).

\section{Area of study}

The selected study area is located in Pandeglang City and some $5 \mathrm{~km}$ from Pandeglang City to the west, which covers an area of about $15 \times 20 \mathrm{~km} 2$. The boundary of studied area is the peak of Gunung Karang $(1778 \mathrm{~m})$ in the north, Gunung Pulosari $(1346 \mathrm{~m})$ in the west, and Pandeglang City to the east. The studied area is the slope of mountains, where the low area is more than 100 meter above sea level, and about 600 meter close to the peak of mountains (fig.1). 


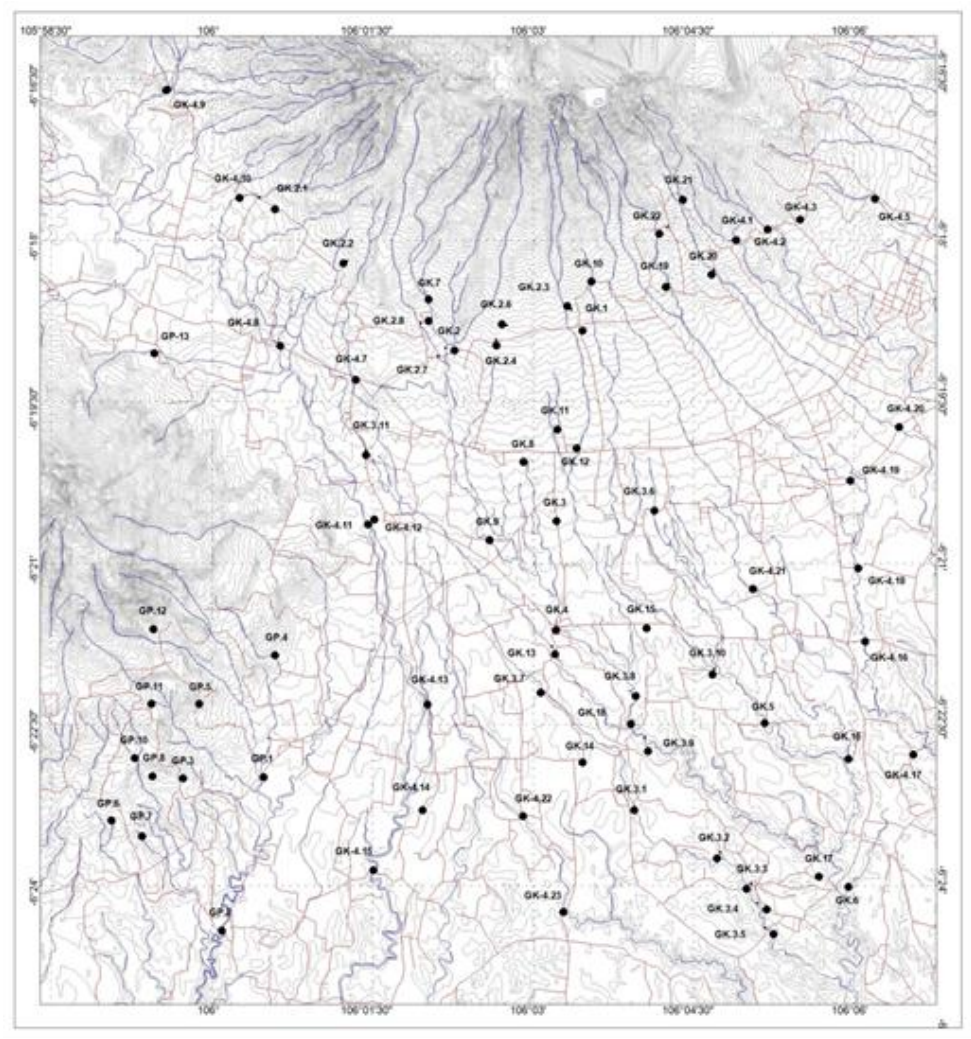

Fig. 1. Studied area represents two mountain peaks, Gunung Karang in the north and Gunung Pulasari in the west. Black circular is the stop site of outcrops observation.

\section{Lithology types}

Several major riverside cliffs and scarps allow detailed observation of the volcanic deposits. Close to the mountain peaks of Gunung Karang and Gunung Pulosari the exposures of the igneous rocks as lava flow are also well exposed in the cliffs of some hill and floor of the intermittent rivers, while pyroclastic (tuff) are well exposed in low land area both in Mandalawangi (in the northwest study area) and Kadugedong (in the southeast study area). Breccia outcrops are common found in the middle of mountain slope in between lava and pyroclastic (tuff).

Volcanic deposits in the slope of southern part Gunung Karang and eastern part of Gunung Pulasari shows distinct lithofacies variations along both the depositional-strike and depositional-dip directions. These volcanic deposits are consisting of ash tuff, lapilli tuff, agglomerate, polymix breccia, volcanic breccia, and andesite lava flow. In the down of the slope of Gunung Karang, ash tuff overlaid unconformable Tertiary deposits. The Tertiary deposits are typified by interbedded mudstone intercalated with thin- to mediumbedded tuffaceous sandstones and siltstone, and are representing the bedding surface direction. But, however, lateral variation of volcanic products, both from Gunung Karang or Gunung Pulasari, are difficult to be found due to intensive cover vegetation and weathering processes.

Gunung Karang and Gunung Pulosari, such as common volcanoes in Java Island, are stratotype volcanoes. The lithology composition is characterized by interbedded of various volcanic eruption materials, such as lava flow, volcanic breccia, pyroclastic and resedimented materials. A total of more than 100 observation sites (fig. 1) represent that the lithology that exposed in the study area consist of volcanic product and Tertiary sedimentary rock. In general the lithologies in the study area are as follow:

1. Tertiary sedimentary rock, which is typified by stratification of tuffaceous mudstones interbedded with finegrained tuffaceous sandstone and siltstone.

2. Product of primary volcanic processes, which is consisting of andesite, volcanic breccia/agglomerate, and pyroclastic rocks (ash tuff, lapilli tuff, bomb/block, and lapilli tuff breccia.

3. Product of secondary volcanic processes, which is consisting of laharic breccia and coarse-grained thick-bedded sandstone.

A. Tertiary sedimentary rock, which is typified by stratification of tuffaceous mudstones interbedded with finegrained tuffaceous sandstone and siltstone. These deposits are exposed in 
floor of River Cibiuk, Ciwalirang in Kp. Cibiuk, Desa Cibodas. The tuffaceous

mudstones are overlaid unconformable by thick ash tuff (fig.2).

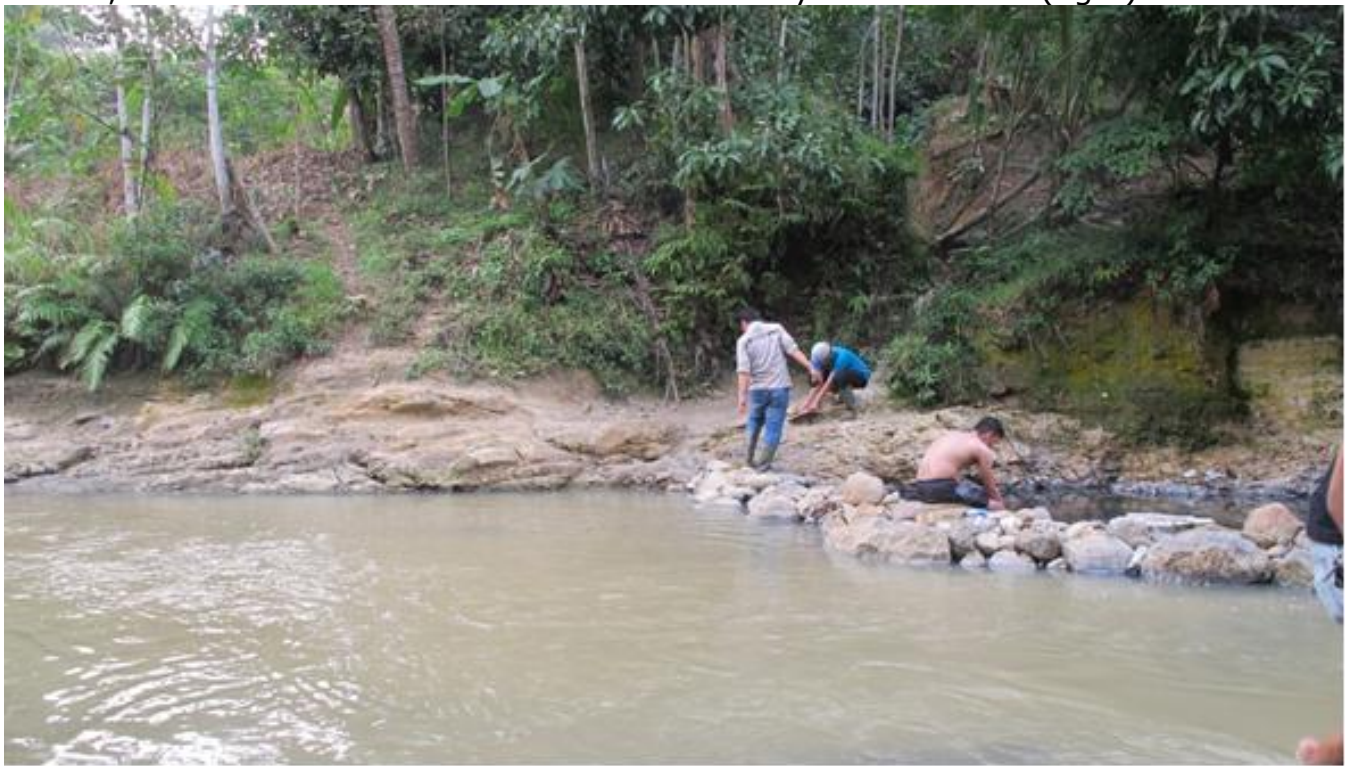

Fig. 2. Outcrop of Tertiary sedimentary rocks, which show interbedded tuffaceous mudstones and fine-grained sandstones. The staff is overlaid unconformable by ash tuff.

B. Product of volcanic processes, which consists of andesite, volcanic breccia/agglomerate, and pyroclastic rocks (ash tuff, lapilli tuff, bomb/block, and lapilli tuff breccia (fig. 3-6). Andesite lava flow is only found at the surface in almost the top of mountain. It is a fine-grained texture, vesicular, composed mainly of plagioclase with other minerals such as hornblende, pyroxene and biotite.

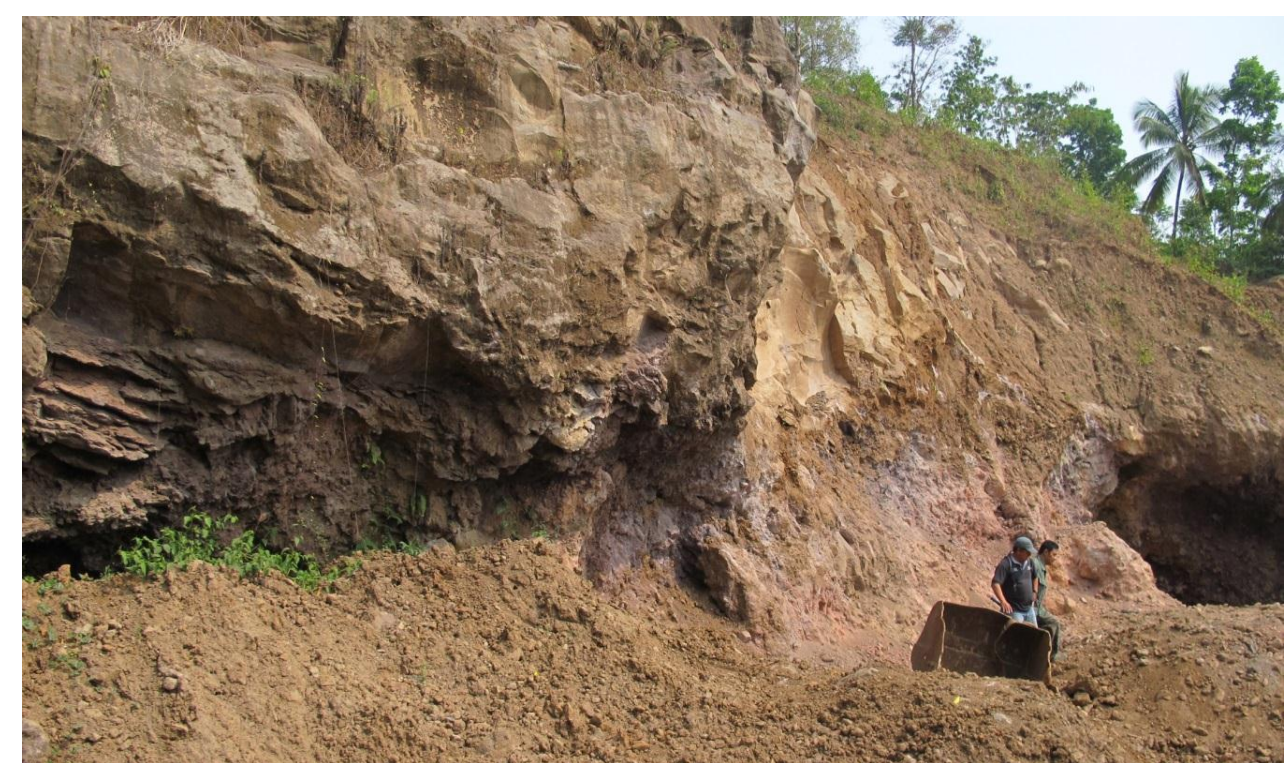

Fig. 3. Adesite lava flow exposed in the northern part of slope of Gunung Pulasari. 


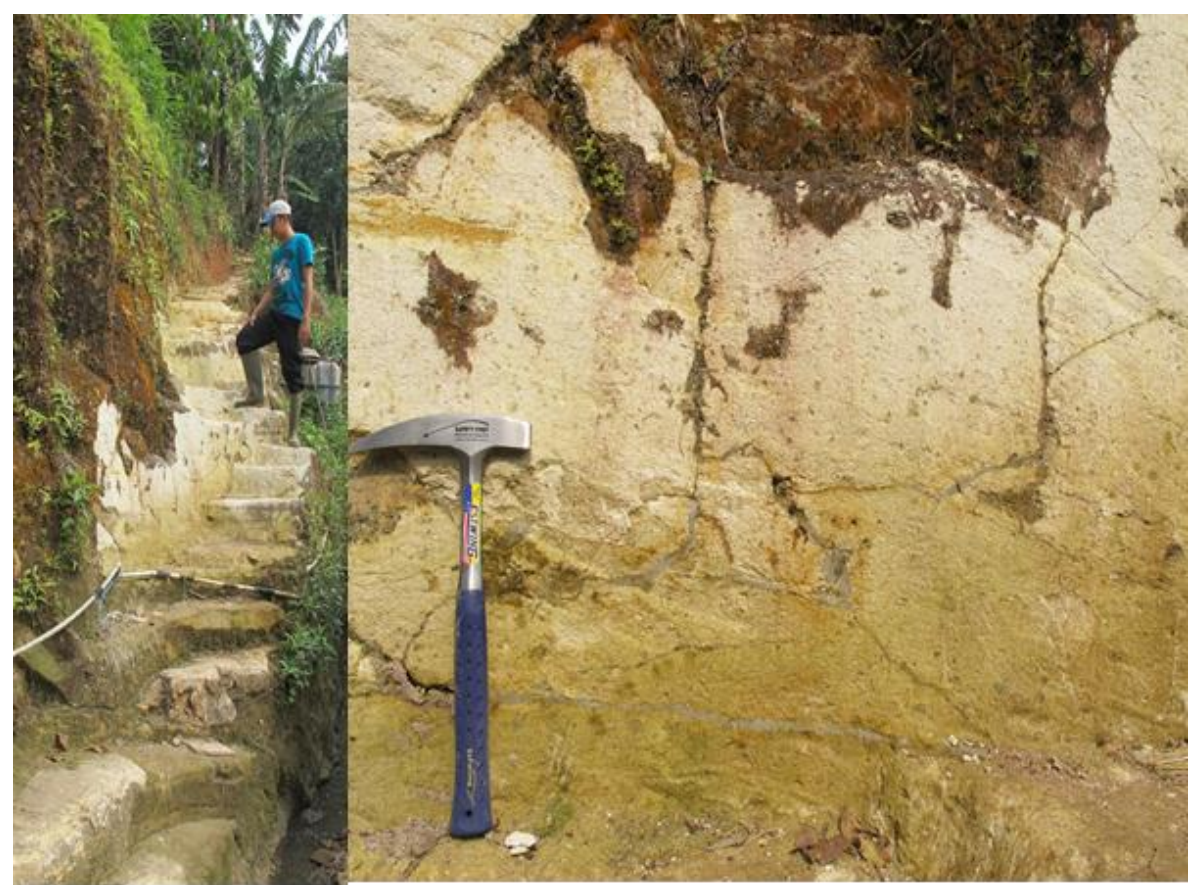

Fig. 4. Ash tuff exposed in the southern part of studied area.

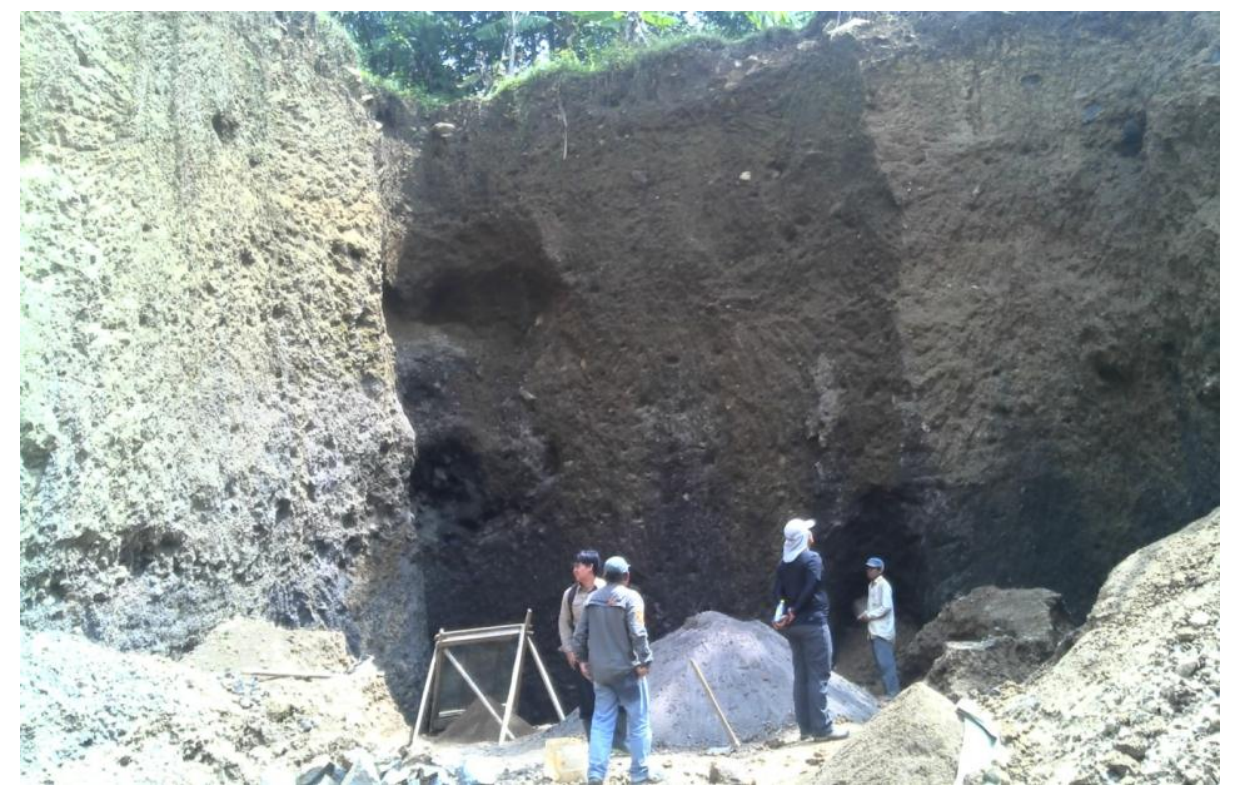

Fig. 5. Very thick deposit of lapilli tuff exposed from Gunung Karang. 


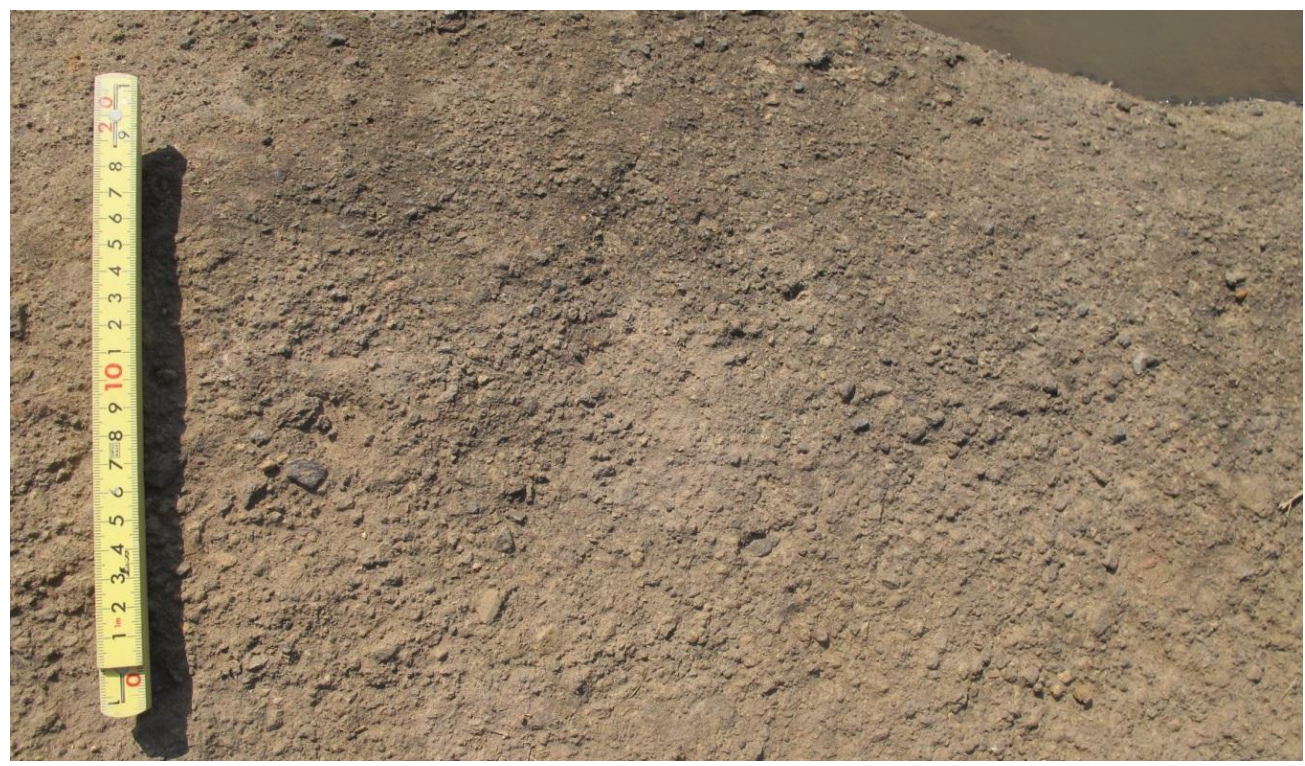

Fig. 6. Tuff lapilli breccia observed

Breccia is the dominant lithology that exposed in the middle slope and lower slope area. There are two types of breccia on basis of product of primary volcanic processes: (1) volcanic breccia and (2) lapilli tuff breccia.

Volcanic breccia is very hard, massive, component supported and very well cemented. The components are consist of igneous rocks in various size $(10-80 \mathrm{~cm}$ in diameter), sub angular-sub rounded, interlocking with sharp basal contact.

Lapilli tuff breccia typified by massive, commonly component supported with locally also matrix supported, well cemented, with the components size is various from $1 \mathrm{~cm}$ until more than $40 \mathrm{~cm}$ in diameter.

In general component supported breccia common found in proximal area, while to the distal matrix supported, together with and polymict breccia (laharic). But however in some locality this phenomenon is change. It suggests that the age of those lithofacies are different. The good exposures of component supported breccia are able to be found in Sungai Cinunggal, Pasir Eurih and Desa Sukamanah.

Ash tuff is found in the relatively flat area close to the toe of slope, in the Cibodas area and in the Mandalawangi area. Ash tuff is characterized by thick- to very thick-bedded fine to very fine grained tuff, white, with locally sporadically associated with coarsegrained to gravel of pumice.

Lapilli tuff and agglomerate are only found in the slope area, in Kp. Garogek (G. Karang), Desa Pasir Eurih (G. Karang) and Desa
Nembola, Kecamatan Mandalawangi (G. Pulasari). Lapilli tuff is characterized by stratification of un-compacted detritus medium - to very coarse-grained sandstone size, slightly constant lateral continuity, and no major thickness changes in outcrops. The deposits are internally massive and are normally graded. Basal contacts are horizontal, sharp and locally undulatory, but not erosional. Agglomerate layers occasionally found with 1-2 meter in thickness, typified by poorly sorted, uncompacted, with the component diameter are varying about $4-30 \mathrm{~cm}$. Whole lapilli tuff and agglomerate is porous.

C. Product of secondary volcanic processes, which is consisting of laharic breccia and coarse-grained thick-bedded sandstone (fig. 7-9). Laharic breccia is commonly typified by components supported, but locally also found matrix supported. The component is various from monomict into polymict. The monomict breccia is commonly found as proximal products, in the middle part of slope, typified by component supported with consist largely by igneous rocks. The polymict breccia common found in the southern part of study area, in Sungai Cilame. It is typified by various components in lithology type and diameter. The components consist of igneous rocks, sedimentary rocks and pyroclastic rocks. 
Bulletin of Scientific Contribution, Volume 14, Nomor 3, Desember 2016 : $277-286$

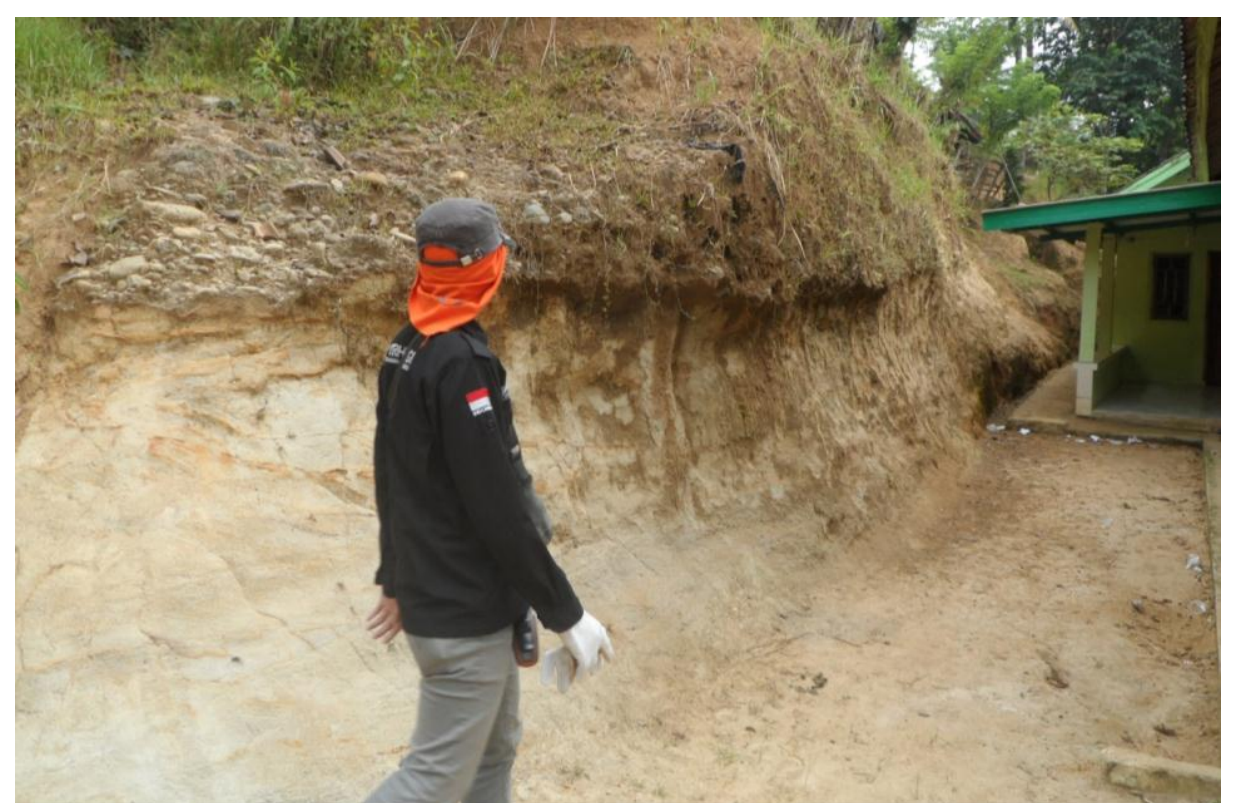

Fig. 7. Outcrop of laharic breccia with erosional basal contact exposed. This deposit overlay ash tuff.

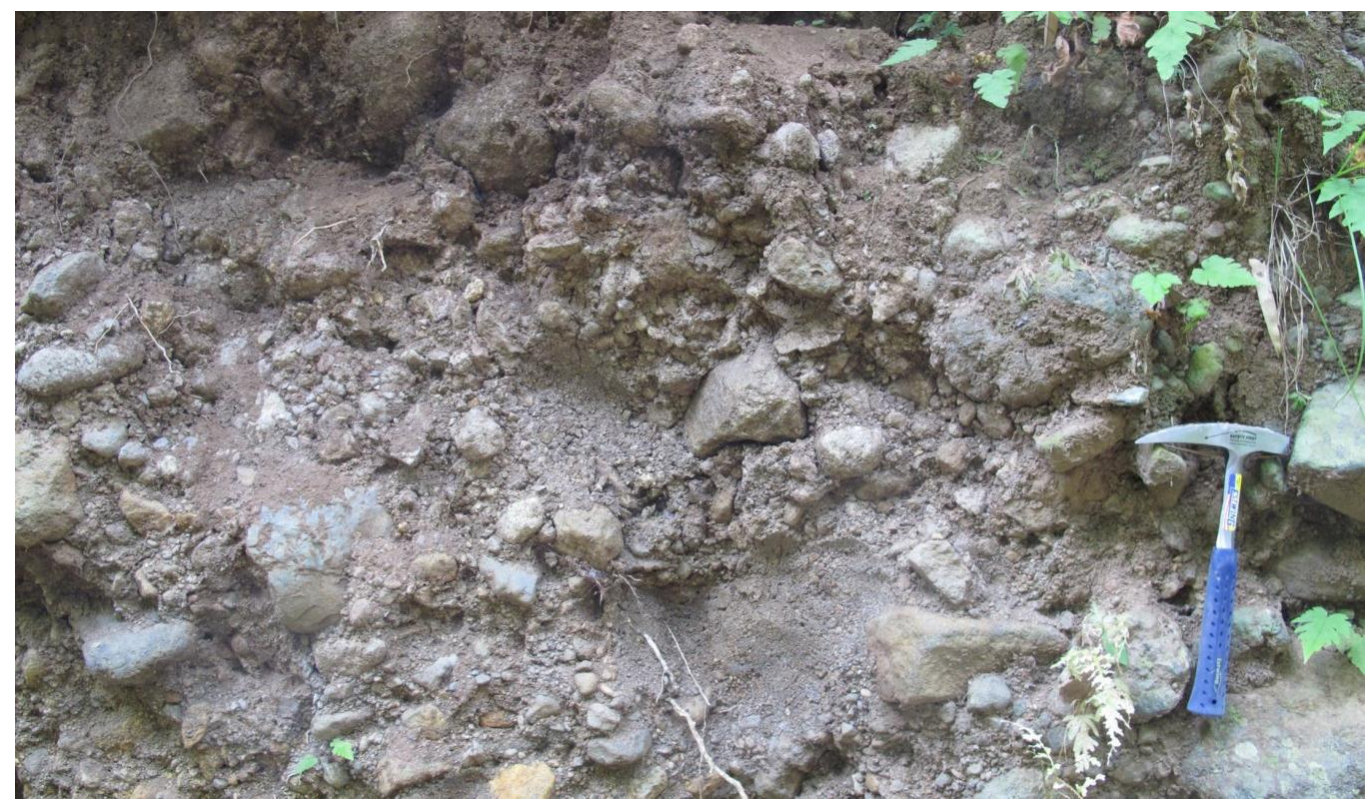

Fig. 8. Matrix supported laharic breccia observed 


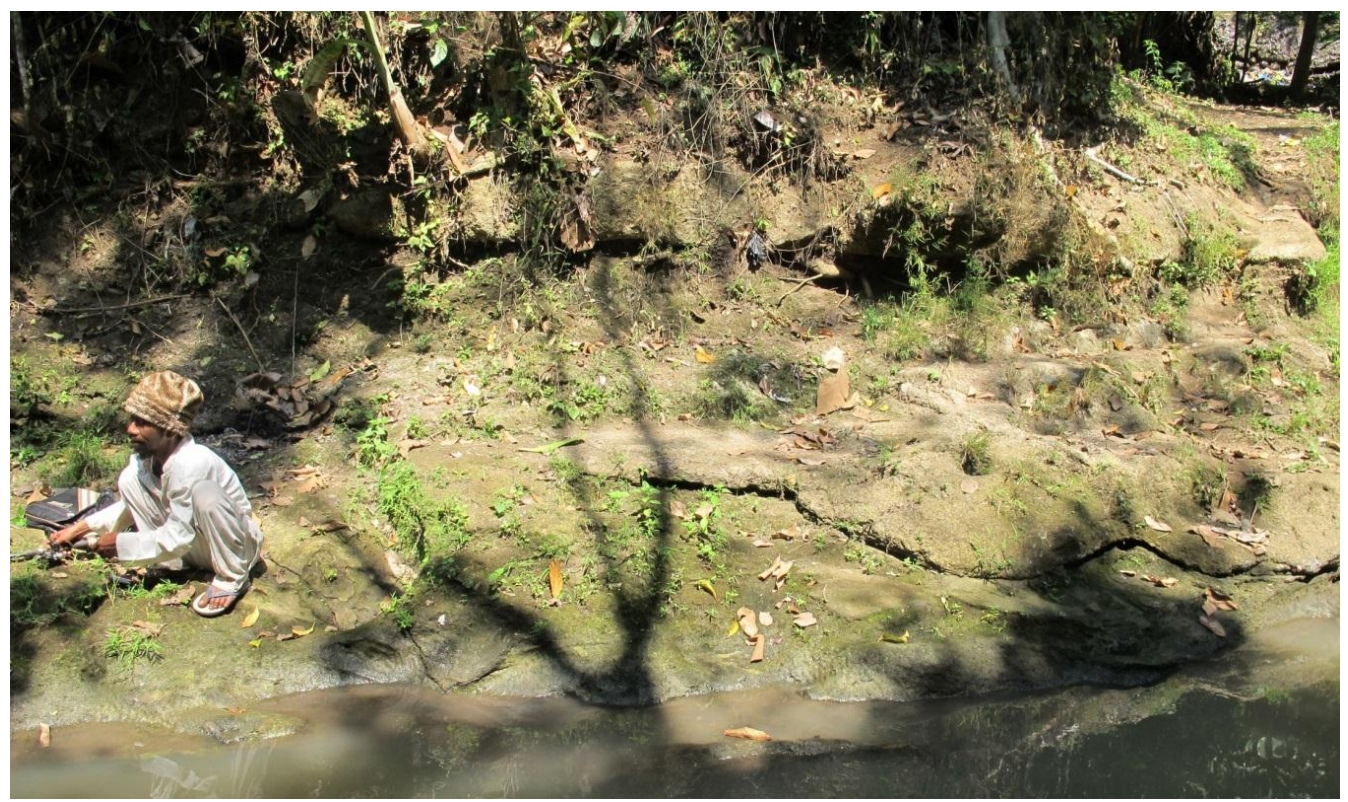

Fig. 9. Outcrop of coarse-grained sandstone exposed

Coarse-grained thick-bedded sandstone is found in the southern part of study area in Sungai Cinunggal. It is characterized by poorly sorted coarse-grained sandstone, undulate bedding with erosional basal contact. This lithology is associated with polymict breccia.

\section{Lithostratigraphy}

The surface lithostratigraphy succession of volcanic product in study area from the oldest to the youngest is (1) Tuffaceous mudstone (Tertiary), (2) Ash tuff, (3) Breccia, and (4)
Andesite lava flow. Even though the surface lithology of volcanic product represent that tuff is the oldest lithology (fig. 10-12), the stratigraphic position in subsurface can change each other's. Since this volcanic succession is a product of multi eruption and produce an interfingering relationship and lithofacies changes laterally. Subsurface geoelectrical survey also conform that in the depth of about 35 meter, there are also layer of andesite lava that the thickness is laterally not persistent and pinching out.

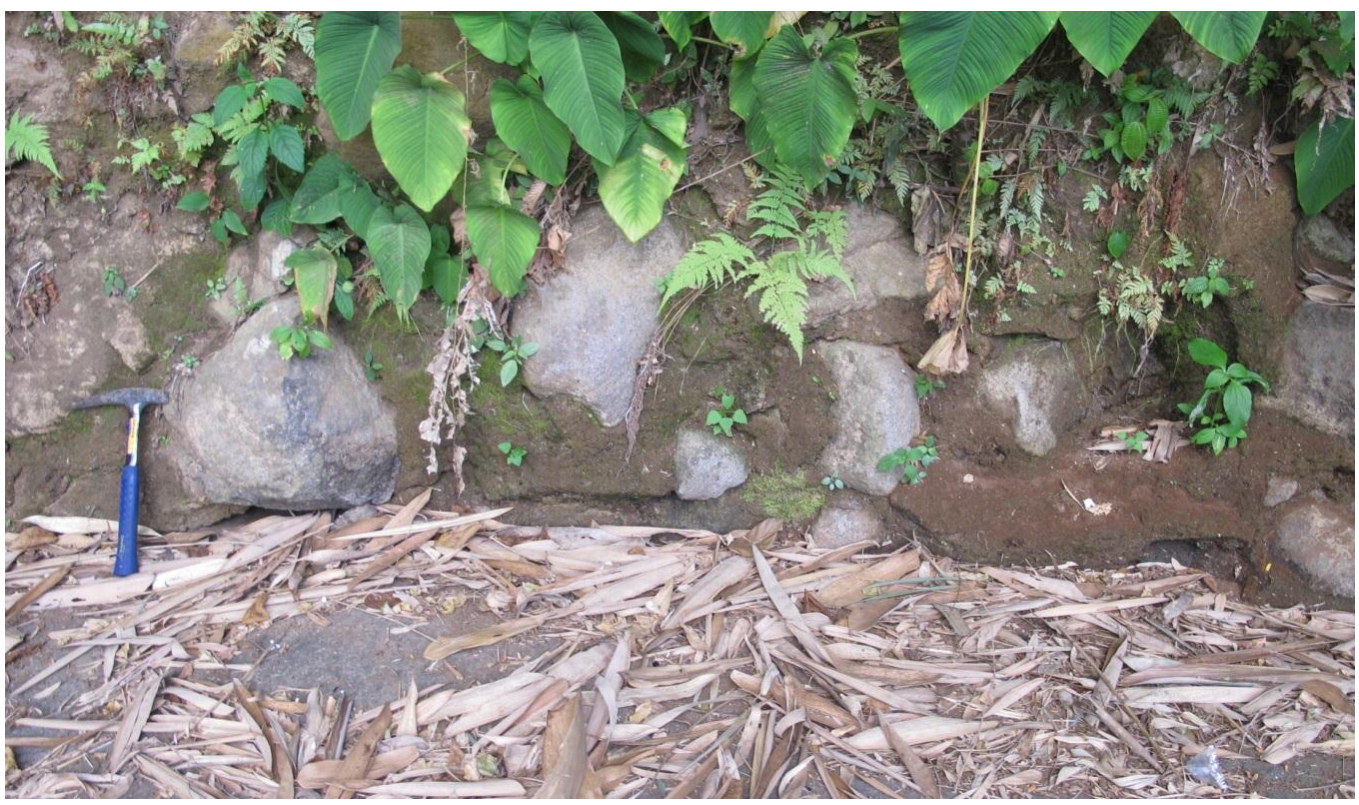

Fig. 10. Outcrop of laharic breccia overlays igneous rock (andesite) 


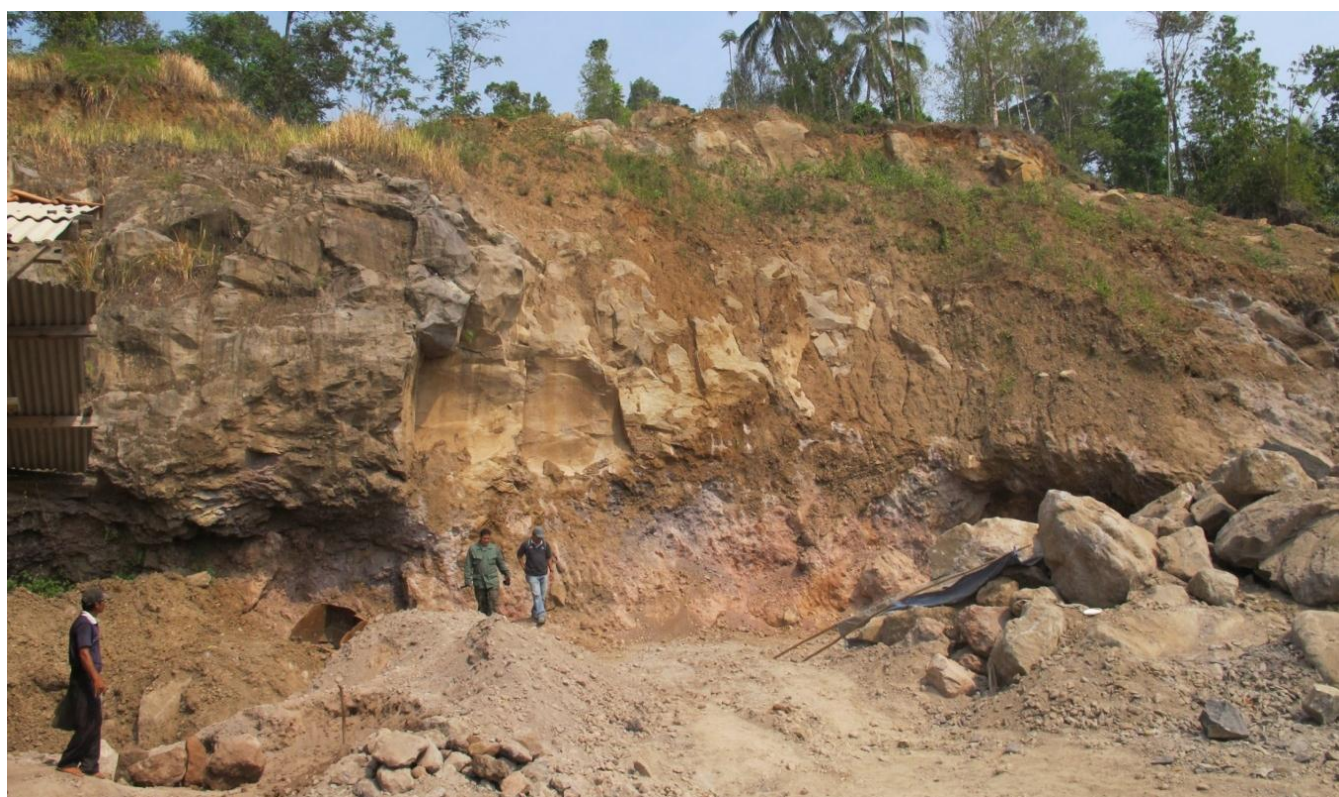

Fig. 11. Andesite lava overlays lapilli tuff exposed in the northern part of slope of Gunung Pulasari.

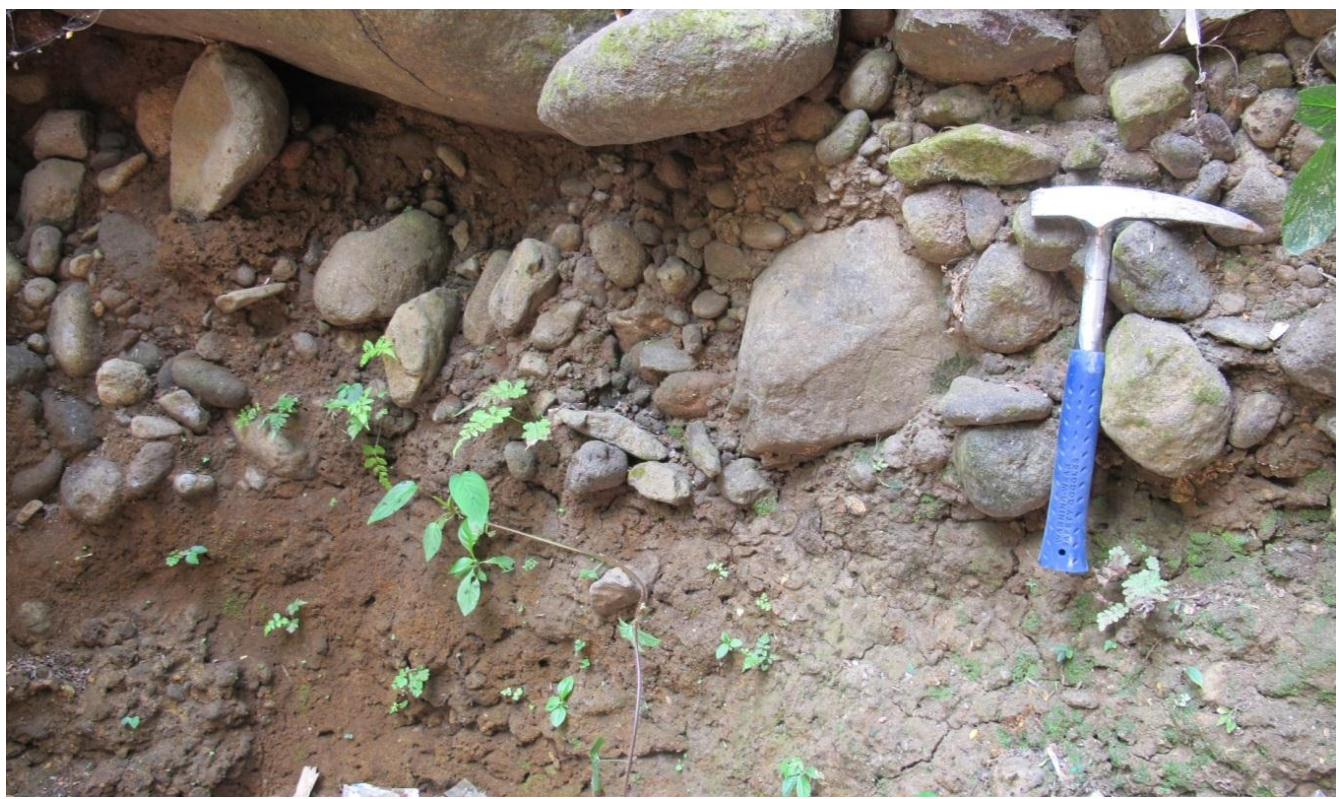

Fig. 12. Outcrop of laharic breccia overlays lapilli tuff in slope of Gunung Karang

\section{Conclusion}

The Quaternary volcanic products from Gunung Karang are consisting of (1) Primary volcanic products: which is consisting of andesite, volcanic breccia/agglomerate, and pyroclastic rocks (ash tuff, lapilli tuff, bomb/block, and lapilli tuff breccia, and (2) Secondary volcanic products, which is consisting of laharic breccia and coarsegrained thick-bedded sandstone.

The stratigraphic position in subsurface can change each other's. Since this volcanic succession is a product of multi eruption and produce an interfingering relationship and lithofacies changes laterally.

\section{Acknowledgment}

We would like to thank to Prof. Hendarmawan and Laboratory of Hydrogeology and Environmental Geology members, who have us an opportunity to join the research group about hydrogeology in volcanic succession in West Java. We would also like to thank to Mas Yudi, Pak Bombom, Pak Yudi, Pak Boy for their help and company us during field work.

\section{Reference}

McPhie, J., Doyle, M., \& Alllen, R. (1993). Volcanic textures: a guide to the interpretation of textures in volcanic rocks. Tasmanian Government Printing Office. 
Bulletin of Scientific Contribution, Volume 14, Nomor 3, Desember 2016 : 277 - 286

Rusmana, E., Suwitodirdjo, K., \& Suharsono. (1991). Geologi Lembar Serang, Jawa. Pusat Penelitian dan Pengembangan Geologi.
Santosa, S. (1991). Geologi Lembar Anyer, Jawa Barat. Pusat Penelitian dan Pengembangan Geologi. 
Bulletin of Scientific Contribution, Volume 14, Nomor 3, Desember 2016 : 277 - 286 